MINERALOGIA, 44, No 1-2: 39-50 (2013)

DOI: 10.2478/mipo-2013-0004

www.Mineralogia.pl

MineRALOGICAL SOCIETY OF POLAND

Polskie TOWARZYSTWO Mineralogiczne

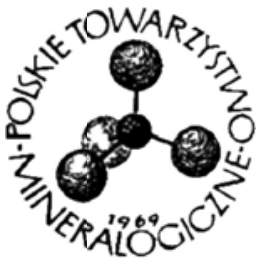

Original paper

\title{
Characterization of barren, granitic soils from the Nubian Desert (SW Egypt) by ${ }^{57}$ Fe Mössbauer spectroscopy
}

\author{
Kamaleldin M. HASSAN ${ }^{1 *}$, Haraldur P. GUNNLAUGSSON ${ }^{2}$ \\ ${ }^{1}$ Department of Radioactive Sedimentary Deposits, Research Sector, Nuclear Materials Authority, P.O. Box 30, \\ Maadi, Cairo, Egypt; email: egy100@yahoo.com \\ ${ }^{2}$ Department of Physics and Astronomy, Aarhus University, Ny Munkegade, 800 Arhus C, Denmark; \\ e-mail:hpg@phys.au.dk \\ * Corresponding author
}

Received: July 17, 2013

Received in revised form: March 3, 2014

Accepted: April 13, 2014

Available online: May 30, 2014

Abstract. ${ }^{57} \mathrm{Fe}$ Mössbauer spectroscopy — a versatile technique involving the recoil-free, resonant absorption and emission of nuclear gamma $(\gamma)$ rays by the iron-57 isotope in natural iron in solids - has been used to provide quantitative information about the mineral host, occupation sites and oxidation states of iron atoms in geological samples. This technique has been applied to the bulk chemistry of a barren soil (Soil A) derived from an aluminous-type granite and another barren soil (Soil B) derived from a sodic-type granite located $\sim 100$ kilometers apart in the Nubian Desert in the currently hyper arid south-west of Egypt and which exhibit distimct chemical and mineral differences. The analyses indicate different mineral hosts for the iron in these samples, namely, vermiculite-chlorite plus some hematite in Soil A and hematite and goethite plus minor aegirines in Soil B. Each soil has distinct intensities of oxidized iron (89\% for Soil A and 100\% for Soil B) and these differences reflect changes in soil sources and processes.

Key-words: Egypt, granites, soils, Mössbauer, Fe oxides, vermiculite-chlorite, smectite

\section{Introduction}

${ }^{57} \mathrm{Fe}$ Mössbauer spectroscopy is an excellent method for the characterization of iron species in soils (see e.g. Cornell, Schwertmann 2003). In contrast to X-ray diffraction, it is 
able to cope with poor mineral crystallinity and/or low iron contents (e.g. Hassan 2010). For example, magnetite $\left(\mathrm{Fe}_{3} \mathrm{O}_{4}\right)$, hematite $\left(\alpha-\mathrm{Fe}_{2} \mathrm{O}_{3}\right)$, maghemite $\left(\gamma-\mathrm{Fe}_{2} \mathrm{O}_{3}\right)$ and goethite $(\alpha-$ $\mathrm{FeOOH})$ in soils are easily distinguished from one another and from iron in layered silicates (Vandenberghe et al. 1992, 1998). In addition, this method is able to estimate the relative proportions of the various $\mathrm{Fe}$ species in heterogeneous specimens. In soils, many iron species, goethite in particular, are often found in nanophase form and contain variable amounts of the aluminum $\left(\mathrm{Al}^{3+}\right)$ ion occupying the ferric $\left(\mathrm{Fe}^{3+}\right)$ iron positions. Both effects (i.e. poor crystallinity, $\mathrm{Al}^{3+}$ substitution) lead to an asymmetric distribution of the magnetic hyperfine field and reduce its average value (Mørup et al. 1983). Mössbauer spectra from soils usually contain asymmetrically broadened peaks and, hence, the areas under the goethite and hematite sextets are not satisfactorily described (e.g. Vandenberghe et al. 1986). To obtain reasonable quantitative- and qualitative results from such spectra, the distributions of the hyperfine field parameters must also be considered (Amarasiriwardena et al. 1986; Vandenberghe et al. 1986).

For this study, two types of soils from the Nubian Desert in south-western Egypt were selected. An aluminous granite-derived soil (Soil A) and a sodic granite-derived soil (Soil B) were analyzed by X-ray diffraction (XRD), inductively coupled plasma-mass spectrometry (ICP-MS) after acid digestion, and 57Fe Mössbauer spectroscopy. Mössbauer data are particularly important in the assignment of the oxidation states of iron and in the determination of iron oxide phases - parameters of considerable geological importance in the evaluation of granitic soils, some of which are enriched in rare elements.

\section{Materials and methods}

Soils A and B (Fig. 1) are dry, with minimal organic matter. Current climatic conditions in the region are hyper arid. Daily maximum temperatures range from $16^{\circ} \mathrm{C}$ during December to $48^{\circ} \mathrm{C}$ in June and rains occur rarely, only every three to four years. Soil A is a soft clayey sand formed within a sandy plain from the weathering of aluminous granites present as small boulders and knobs. These granites, which are characterized by molar alumina to total alkalis plus lime ratios of $>1$ (Hassan 2008), may be related to tonalitegranodiorite emplaced during the Proterozoic in Egypt (Sabet 1972). They consist of albite, quartz, and K-feldspar, with variable amounts of biotite, phlogopite, and hornblende.

Soil B, on the other hand, is a loamy sand deposit only a few centimeters thick formed at the foot of a mountain that is made up of mainly sodic granites with molar soda plus potash to alumina ratios of $>1$ (Hassan 2005). These granites consist of microcline, quartz and albite plus some iron-bearing silicates, including aegirine-augite and aegirine \pm minor riebeckite. Typical of the peralkaline acidic rocks often found in ring complexes and dikelike intrusions in Egypt (List et al. 1989), they characteristically contain high abundances of iron (mainly ferric), uranium, thorium, neodymium, cerium, zirconium, yttrium, niobium and samarium (Hassan 2009, 2010). Radiometrically, Soil B has up to eight times more total field $\gamma$-ray radiation than Soil A, but no obvious mineralization. The radioactivity is due mainly to thorium and, to a lesser extent, uranium. 


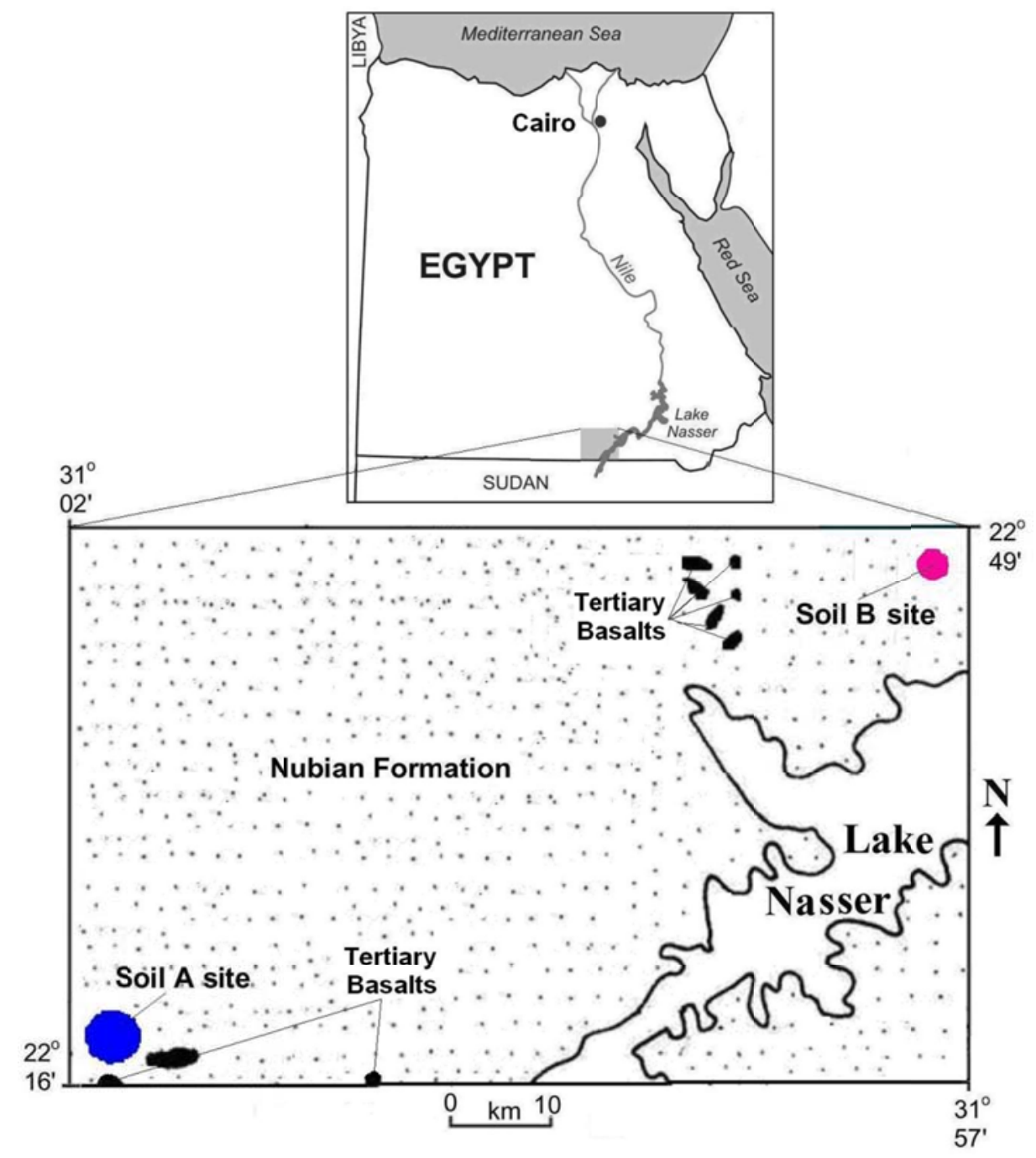

Fig. 1. Simplified geologic map of southern Egypt (revised from Egyptian Geological Survey and Mining Authority, 1981).

Bulk samples of Soil $\mathrm{A}\left(\mathrm{A} 1_{\text {bulk }}\right.$ and $\left.\mathrm{A} 2_{\text {bulk }}\right)$ and of Soil $\mathrm{B}\left(\mathrm{B} 1_{\text {bulk }}\right.$ and $\left.\mathrm{B} 2_{\text {bulk }}\right)$ were selected and processed for laboratory analyses. Each is a mixture of grab samples collected from various soil collection sites and intended to produce a typical or average sample. The samples have similar $\mathrm{pH}$ values (7.8-7.9). $\mathrm{A} 1_{\text {bulk }}$ and $\mathrm{A} 2_{\text {bulk }}$ have a moderate orange-pink color (10 R 6/6) while $\mathrm{B} 1_{\text {bulk }}$ and $\mathrm{B} 2_{\text {bulk }}$ have a moderate reddish-orange color (10 R 7/4).

Bulk-sample chemical analyses were made at Acme Analytical Laboratories, Vancouver, Canada, using four-acid digestion ICP-MS. Bulk-sample mineralogy was made by XRD using a Philips $1710 \mathrm{X}$-ray diffractometer ( $\mathrm{Cu}-\mathrm{K} \alpha$ radiation; scanning rate $0.02^{\circ} 2 \theta / \mathrm{s}$; peak angle range $2-60^{\circ} 2 \theta$ ). For accurate clay mineral identification, the clay-rich fraction of the samples was separated by centrifuge. Three oriented slides of this fraction, 
one without treatment, a second after exposure to glycerol vapor in vacuum desiccators at $60^{\circ} \mathrm{C}$ for 2 hours and a third heated to $550^{\circ} \mathrm{C}$ for 6 hours, were analyzed on a Philips X'Pert diffractometer (scanning rate $0.02^{\circ} 2 \theta / \mathrm{s}$; peak angle range $2-35^{\circ} 2 \theta$ ). The X-ray diffractograms were compared with JCPDS files for mineral identification.

For Mössbauer measurements, aliquots of all four samples were milled in an agate mortar to as fine a texture as possible. In order to get a better picture of the magnetic part of Soil A (relatively low in $\mathrm{Fe}$ ), a magnetic separate of $\mathrm{A} 1_{\text {bulk }}$ was prepared by dispersing the sample in ethanol in a glass, applying a hand magnet to the side of the glass and pouring the liquid off. This process was repeated several times until the poured-off liquid was visually clean. The magnetic separate was then dried at room temperature. Mössbauer spectra were obtained for the four bulk samples and the $\mathrm{A} 1_{\text {magnetic separate }}$ at room temperature using a conventional drive system with a ${ }^{57} \mathrm{Co}(\mathrm{Rh})$ source of $\sim 10 \mathrm{mCi}$ in transmission geometry. The spectra obtained were fitted to Lorentzian line shapes to obtain accurate line parameters including the average hyperfine magnetic field $\left(B_{\mathrm{hf}}\right.$ average), the most-probable hyperfine magnetic field peak $\left(B_{\mathrm{hf} \text {, peak }}\right)$, the isomer shift $(\delta)$, the quadrupole splitting $\left(\Delta E_{\mathrm{Q}}\right)$, the line width $(\Gamma)$ and the relative spectral area (RA). The $\delta$ values are given relative to metallic iron at room temperature. Accuracies for all of the measured hyperfine parameters are between 1 and $8 \%$.

\section{Results and Discussion}

The ICP-MS results are listed in Table 1 along with the chemical data of the parent granites from Hassan $(2005,2009)$. Soil A is richer in magnesium oxide than Soil B and poorer in total iron (as ferric) and potassium oxide. Soil B has relatively high concentrations of thorium, zirconium, cerium, yttrium and niobium that reside in trace mineral phases or are adsorbed onto mineral surfaces, mainly Fe-oxides (Hassan 2010). The differences in element content observed between Soil A and Soil B largely reflect parent material and local topography as climate is essentially the same at both sampling sites.

XRD patterns for the bulk samples of Soil A and Soil B, with mineral identifications, are given in Figure 2 along with XRD data for the parent granites from Hassan (2009). In the soil samples, quartz was identified by XRD as the major component. The quartz is associated with lesser amounts of K-feldspar or albite plus minor amounts of unidentified clay and minor amounts of calcite. A weak diffraction peak $\left(2 \theta \approx 30.2^{\circ}\right)$ in Soil B may be due to the 104 (hkl) diffraction peak of hematite which was identified by Mössbauer spectroscopy. Hematite (and other ferric-oxide phases) forms on weathered surfaces, such as those of the present study, and usually does not exhibit long-range order. Such materials are difficult to identify by XRD, but are certainly identified by Mössbauer spectroscopy on the basis of their magnetic properties. 


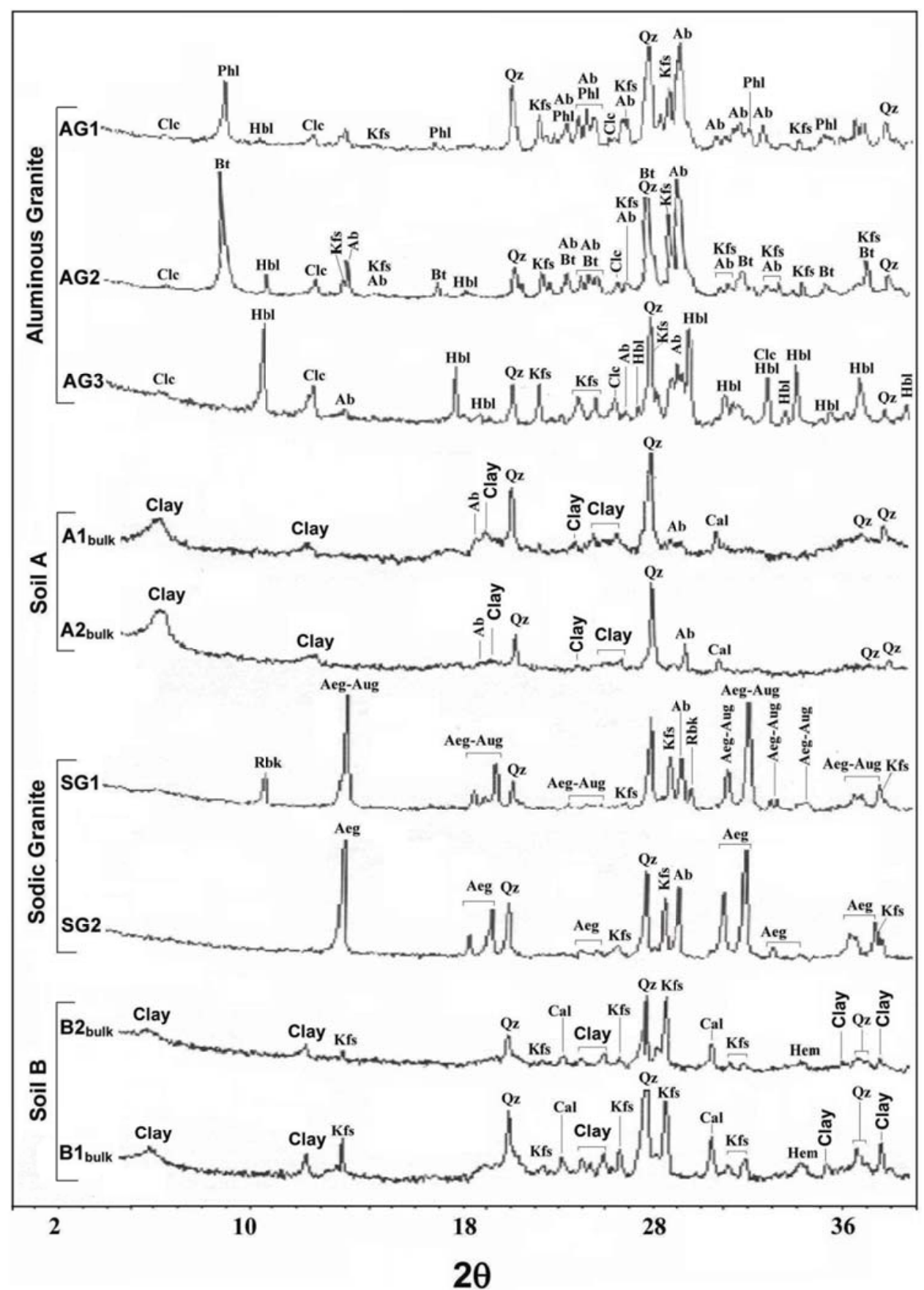

Fig. 2. XRD diffractograms of the soils and parent granites. Mineral abbreviations in alphabetical order: Aeg (aegirine), Aeg-Aug (aegirine-augite), Ab (albite), Bt (biotite), Cal (calcite), Clc (clinochlore), Hem (hematite), Hbl (hornblende), Kfs (K-feldspar), Phl (phlogopite), Qz (quartz), Rbk (riebeckite). 
Figure 3 shows examples of XRD patterns between 2 and $26^{\circ} 2 \theta$ from the clay-rich fractions of Soil A and Soil B, before and after glycerol treatment and also after heating $\left(6 \mathrm{hr}\right.$ at $\left.550^{\circ} \mathrm{C}\right)$. Expansion occurs from 14.9 to $16.52 \AA$ for glycerolized Soil A, suggesting the presence of smectite together with kaolinite, and from 14.27 to $14.55 \AA$ for glycerolized Soil B, suggesting vermiculite-chlorite mixed layer minerals. In heated samples, the interlayer of the smectite collapses to $9.9 \AA$ and the vermiculite interlayer to $13.9 \AA$, consistent with the presence of chlorite and the parent granites containing clinochlore as a secondary mineral. In general, vermiculite expands to the equivalent one-layer complex of glycerol with d-spacing values of 13.6-15.3 $\AA$, while dioctahedral smectites with Al-Mg substitution, mainly in the octahedral sites, yield two-layer complexes with glycerol of up to $17.7 \AA$ (Harward et al. 1969). It should be mentioned that clay mineral identification in geological samples needs a lot of further effort for definitive results, i.e. saturations also with $\mathrm{Mg}^{2+}$ and $\mathrm{K}^{+}$which were not available.

Natural vermiculites are typically formed from weathering or hydrothermal alteration of biotite or phlogopite. Previous studies of the phlogopite $\rightarrow$ mixed layer $\rightarrow$ vermiculite sequence indicate that the oxidation of Fe occurs mainly in the octahedral sites and that the mobilization and oxidation of the ferrous ions from the octahedral- to tetrahedral sites may take place during the transformation of phlogopite into a mixed-layer phase (Badreddine et al. 2000). Finally, this process (vermiculitization) involves both Fe oxidation and the removal of $\mathrm{K}$ with a simultaneous increase in the $\mathrm{Mg}$ content (Badreddine et al. 2000).

The Mössbuer spectra of all of the samples analyzed are displayed in Figure 4. As the spectra of the two bulk samples of each soil were identical within experimental error, average parameters are given in Table 2 . The spectrum of $\mathrm{A} 1_{\text {magnetic separate }}$ (except relative subspectral intensities) is also typical of the Soil A bulk-sample spectrum. All of the spectra were analyzed in terms of four components, namely, a doublet (D1) due to (super)paramagnetic ferric iron, a doublet (D2) (found only in the Soil A bulk-samples and $\mathrm{A} 1_{\text {magnetic separate }}$ ) due to paramagnetic ferrous iron, a relatively sharp-lined sextet assigned to hematite (S1) and a broad-lined sextet (S2) assigned to goethite (found only in Soil B). To account for asymmetries in the line shapes, the two latter components were analyzed with a magnetic hyperfine field distribution (Gunnlaugsson 2006).

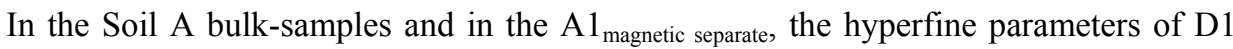
are consistent with $\mathrm{Fe}^{3+}$ in octahedral coordination in vermiculite (Badreddine et al. 2002). They are also consistent with superparamagnetic hematite with a blocking temperature below room temperature (Kündig et al. 1966). D1 of the Soil B bulk-samples has lower quadrupole splitting than that of the Soil $\mathrm{A}$ bulk-samples and $\mathrm{A} 1_{\text {magnetic separate, suggesting }}$ different environments for the ferric iron in the two soils. For Soil B, it is considered to be $\mathrm{Fe}^{3+}$ in octahedral coordination from aegirines, common minerals in the rocks from which this soil formed. 


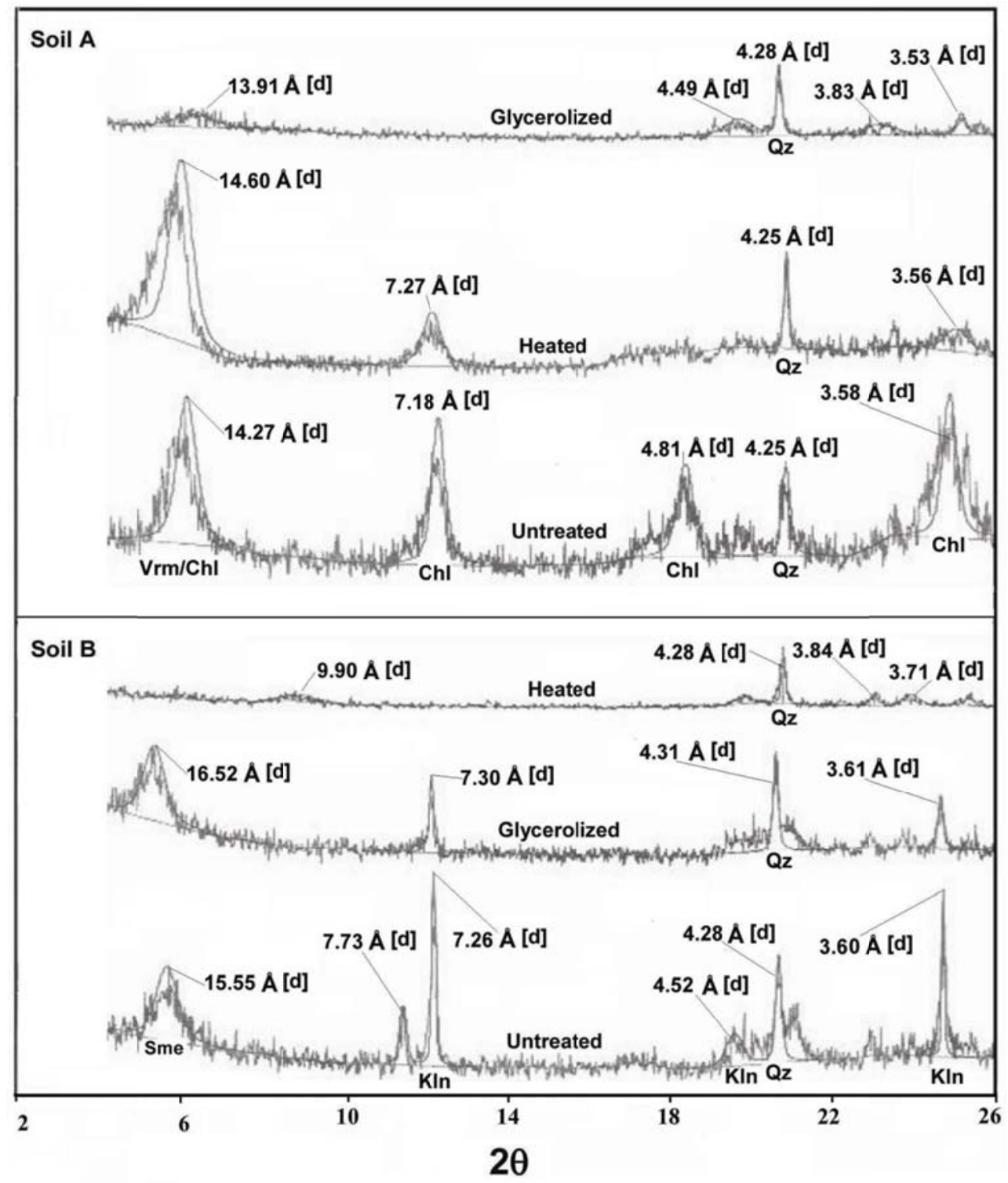

Fig. 3. XRD diffractograms of the clay-rich fractions of Soil A and Soil B. Mineral abbreviations in alphabetical order: Chl (chlorite), Kln (kaolinite), Qz (quartz), Smectite (sme), Verm-Chl (vermiculite-chlorite). 

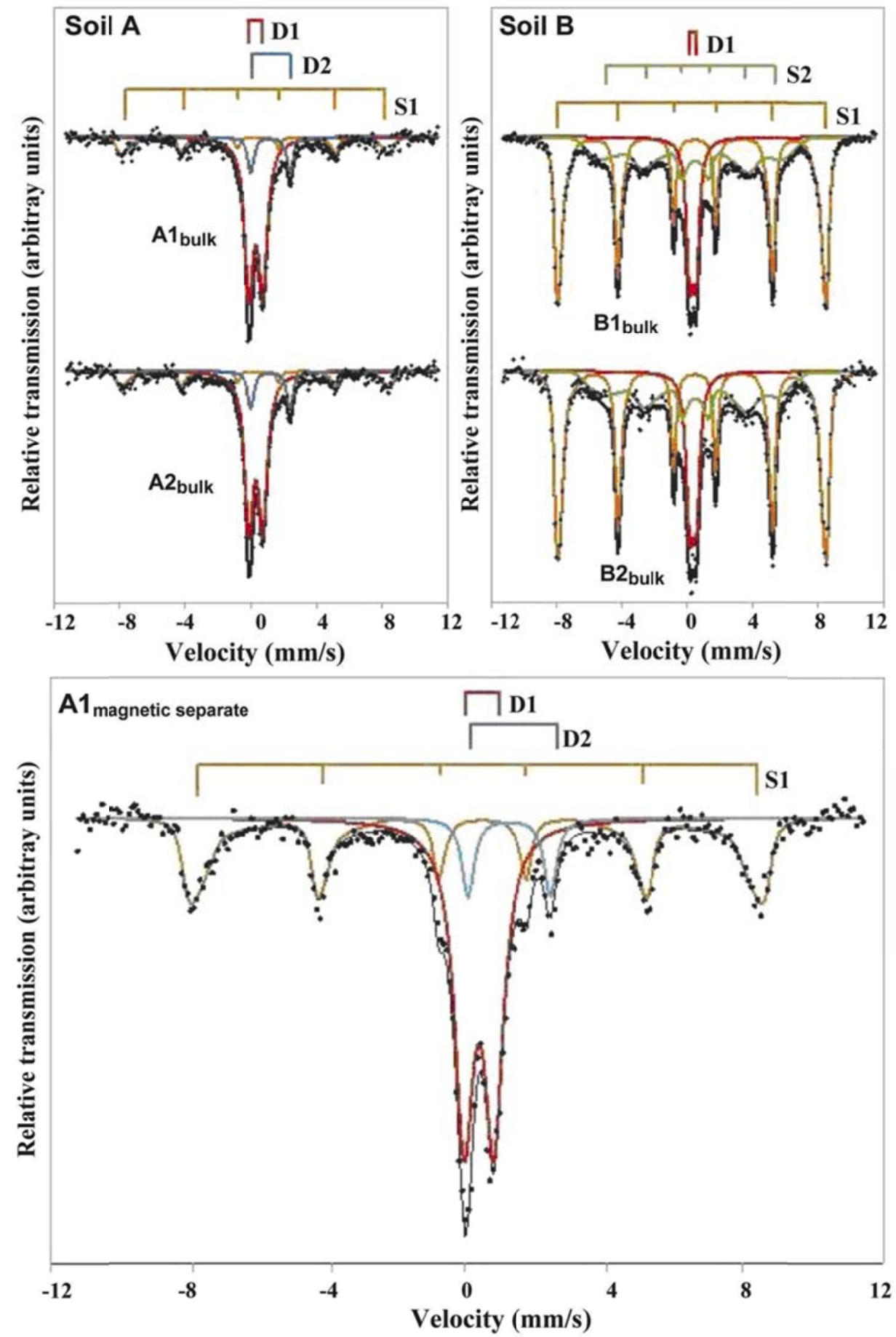

Fig. 4. Room-temperature Mössbauer spectra of Soil A and Soil B samples. The solid lines indicate the fitting components indicated with a bar-diagram. 
Chemical analyses of the soils studied and their source granites

\begin{tabular}{|c|c|c|c|c|c|c|c|c|c|}
\hline & \multicolumn{2}{|l|}{ Soil A } & \multicolumn{3}{|c|}{ Aluminous Granite } & \multicolumn{2}{|l|}{ Soil B } & \multicolumn{2}{|c|}{ Sodic Granite } \\
\hline & $\mathrm{A} 1_{\text {bulk }}$ & $\mathrm{A} 2_{\text {bulk }}$ & AG1 & AG21 & AG3 & $\mathrm{B} 1_{\text {bulk }}$ & $\mathrm{B} 2_{\text {bulk }}$ & SG1 & SG2 \\
\hline \multicolumn{10}{|l|}{$(\% w t)$} \\
\hline $\mathrm{Al}_{2} \mathrm{O}_{3}$ & 11.11 & 7.47 & 12.8 & 13.3 & 12.8 & 8.96 & - & 8.4 & 7.40 \\
\hline$\left(\mathrm{Fe}_{2} \mathrm{O}_{3}\right)_{\text {total }}$ & 7.52 & 5.34 & 8.73 & 6.80 & 4.20 & 12.34 & - & 10.09 & 10.21 \\
\hline $\mathrm{MnO}$ & 0.07 & 0.08 & 0.16 & 0.10 & 0.16 & 0.19 & - & 0.13 & 0.25 \\
\hline $\mathrm{MgO}$ & 7.45 & 4.70 & 0.84 & 2.00 & 0.84 & 0.45 & - & 0.21 & 0.70 \\
\hline $\mathrm{CaO}$ & 2.37 & 5.39 & 1.00 & 2.80 & 1.0 & 2.51 & - & 1.96 & 1.00 \\
\hline $\mathrm{Na}_{2} \mathrm{O}$ & 0.65 & 0.27 & 3.36 & 3.80 & 3.36 & 0.53 & - & 1.88 & 4.6 \\
\hline $\mathrm{K}_{2} \mathrm{O}$ & 0.84 & 1.22 & 3.30 & 4.23 & 3.30 & 3.34 & - & 5.90 & 3.97 \\
\hline $\begin{array}{l}\mathrm{P}_{2} \mathrm{O}_{5} \\
(\mathrm{ppm})\end{array}$ & 0.20 & 0.16 & 0.22 & 0.20 & 0.22 & 0.14 & - & 0.15 & 0.22 \\
\hline $\mathrm{U}$ & 1.5 & 1.2 & 2.4 & - & 5.5 & 9.9 & 13.4 & 13.8 & 4.9 \\
\hline Th & 7.2 & 7.9 & 20.1 & - & 70.2 & 55.6 & 43.4 & 105.8 & 40.7 \\
\hline $\mathrm{Rb}$ & 26.2 & 27.4 & 113 & - & 61.3 & 137.4 & 134.4 & 193.8 & 182.8 \\
\hline $\mathrm{Zr}$ & 140.4 & 110.6 & 69.1 & - & 87 & 1129.4 & 2488.8 & 1653 & 654.2 \\
\hline $\mathrm{Ce}$ & 71 & 57 & 134 & - & 208 & 861 & 868.1 & 1073 & 826 \\
\hline $\mathrm{Y}$ & 20.1 & 13.5 & 26.5 & - & 33.6 & 166.6 & 250.5 & 222.9 & 1242 \\
\hline $\mathrm{Nb}$ & 28.3 & 27.3 & 19.3 & - & 19.1 & 322.2 & 364.0 & 427.6 & 388.4 \\
\hline
\end{tabular}

Dash - not analyzed

D2, which is only observed in the Mössbauer spectra of the Soil A bulk-samples and the $\mathrm{A} 1_{\text {magnetic separate, }}$ has isomer shift values that are consistent with $\mathrm{Fe}^{2+}$ in octahedral sites in vermiculite (Badreddine et al. 2002), but lower quadrupole splittings $(2.25 \mathrm{~mm} / \mathrm{s})$. These low values may reflect abundant $\mathrm{Fe}^{3+}$ ions in octahedral coordination (Taylor et al. 1968).

The hyperfine parameters of the S1 sextet (Table 2) have been attributed to hematite. These parameters are in good agreement with those reported for hematite from burned soil profiles in Denmark (Vendelboe et al. 2005). Due to small particle effects (and possibly due to $\mathrm{Al}$ substitution in part), the hyperfine field distribution will have a tail toward zero and, thus, the $B_{h f}$ average value is smaller than the maximum probability or the $B_{h f, \text { peak }}$ value (cf. Table 2). The ratio of the two field values in a Mössbauer spectrum is an indirect measure of the particle size distribution in the sample. For the hematite, it is more crystalline in the

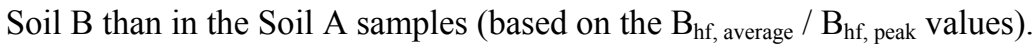

The S2 sextet is assigned to goethite owing to similarities with a standard spectrum of goethite in soils (see, e.g. Nørnberg et al. 2004). Its average magnetic hyperfine field is much less than the peak magnetic hyperfine field (cf. Table 2), consistent with poorly crystalline- or Al-substituted goethite. In soils, goethite consists of nano-particle precipitates and/or is poorly crystalline - a feature that leads to an asymmetric distribution of the magnetic hyperfine field and decreases its value (Mørup et al. 1983). Other studies indicate a clearer correlation between the hyperfine field and the goethite content of soil 
samples (Vandenberghe et al. 1986). This suggests that the crystallinity of goethite increases with the amount of goethite relative to the total of all $\mathrm{Fe}$ oxides.

TABLE 2

Average hyperfine parameters of the soils and parent granites (experimental error $\left(\begin{array}{lll} \pm & \sigma\end{array}\right)$ in parenthesis)

\begin{tabular}{|c|c|c|c|c|c|c|c|c|c|}
\hline \multirow{2}{*}{ Sample } & \multirow{2}{*}{$\begin{array}{l}B_{\text {hf, peak }} \\
(\mathrm{T})\end{array}$} & \multirow{2}{*}{$\begin{array}{l}B_{\mathrm{hf} \text {, average }} \\
(\mathrm{T})\end{array}$} & \multirow{2}{*}{$\begin{array}{l}\delta \\
\mathrm{mm} / \mathrm{s}\end{array}$} & \multirow{2}{*}{$\begin{array}{l}\Delta E_{\mathrm{Q}} \\
\mathrm{mm} / \mathrm{s}\end{array}$} & \multirow{2}{*}{$\begin{array}{l}\Gamma \\
\mathrm{mm} / \mathrm{s}\end{array}$} & \multicolumn{2}{|l|}{$\begin{array}{l}\text { RA } \\
(\%)\end{array}$} & \multicolumn{2}{|c|}{ Interpretation } \\
\hline & & & & & & $\begin{array}{l}\text { Bulk } \\
\text { sample }\end{array}$ & $\begin{array}{l}\text { Magnetic } \\
\text { separate }\end{array}$ & $\begin{array}{l}\mathrm{Fe} \\
\text { site }\end{array}$ & $\begin{array}{l}\text { Major } \\
\text { phases }\end{array}$ \\
\hline \multicolumn{10}{|l|}{ Soil A } \\
\hline & $51(2)$ & $43(2)$ & $0.38(4)$ & $-0.21(7)$ & & $25(7)$ & $38(2)$ & $\mathrm{S} 1-\mathrm{Fe}^{3+}$ & Hematite \\
\hline & & & $0.33(1)$ & $0.86(2)$ & $0.63(3)$ & $64(5)$ & $53(2)$ & $\left.\mathrm{D} 1-\mathrm{Fe}^{3+}\right]$ & Vermiculite- \\
\hline & & & $1.25(3)$ & $2.35(6)$ & $0.38(8)$ & $11(2)$ & $8(2)$ & $\left.\mathrm{D} 2-\mathrm{Fe}^{2+}\right\}$ & chlorite \\
\hline \multicolumn{10}{|c|}{ *Aluminous } \\
\hline \multicolumn{10}{|c|}{ Granite } \\
\hline & & & $0.50(1)$ & $0.73(3)$ & $0.64(5)$ & & $33.7(5)$ & $\mathrm{D} 1-\mathrm{Fe}^{3+}$ & Biotite + \\
\hline & & & $1.1(1)$ & $2.58(1)$ & $0.42(4)$ & & $66.3(5)$ & $\mathrm{D} 2-\mathrm{Fe}^{2+}$ & $\begin{array}{l}\text { Phlogopite + } \\
\text { Hornblende }\end{array}$ \\
\hline \multicolumn{10}{|l|}{ Soil B } \\
\hline & $\begin{array}{l}51.5(7) \\
43.4(6)\end{array}$ & $\begin{array}{l}49.9(7) \\
26.7(67)\end{array}$ & $\begin{array}{l}0.38(3) \\
0.35(7)\end{array}$ & $\begin{array}{l}-0.21(5) \\
0.33(1)\end{array}$ & & $\begin{array}{l}51(2) \\
32(4)\end{array}$ & & $\begin{array}{l}\mathrm{S} 1-\mathrm{Fe}^{3+} \\
\mathrm{S} 2-\mathrm{Fe}^{3+}\end{array}$ & $\begin{array}{l}\text { Hematite } \\
\text { Goethite }\end{array}$ \\
\hline & & & $0.37(7)$ & $0.40(1)$ & $0.43(3)$ & $17(4)$ & & $\left.\mathrm{D} 1-\mathrm{Fe}^{3+}\right\}$ & $\begin{array}{l}\text { Aegirine + } \\
\text { Aegirine- } \\
\text { augite }\end{array}$ \\
\hline \multicolumn{10}{|l|}{ *Sodic } \\
\hline & & & $0.39(4)$ & $0.35(2)$ & $0.38(13)$ & & $82.1(4)$ & $\left.\mathrm{D} 1-\mathrm{Fe}^{3+}\right]$ & Aegirine + \\
\hline & & & $1.18(1)$ & $2.61(3)$ & $0.54(13)$ & & $17.9(4)$ & $\mathrm{D} 2-\mathrm{Fe}^{2+}$ & $\begin{array}{l}\text { Aegirine- } \\
\text { augite }\end{array}$ \\
\hline
\end{tabular}

*Data from Hassan (2010)

The degree of oxidation $\left(\mathrm{Fe}^{3+} / \Sigma \mathrm{Fe}\right)$, determined directly from the relative spectral areas or RA values (Table 2), is found to be $89 \%$ in Soil A and $100 \%$ in Soil B. The interpretation of soil oxidation states is by no means simple. The ratio $\mathrm{Fe}^{3+} / \Sigma \mathrm{Fe}$ in soils is mainly a function of source materials and the availability of oxygen or $f \mathrm{O}_{2}$ during soil formation. Soil $\mathrm{A}$ is derived from aluminous granites low in ferric iron (average $\mathrm{Fe}^{3+}=$ $33.7 \%$ ) whereas sample Soil B is derived from sodic granites that are high in ferric iron $\left(\mathrm{Fe}^{3+}=82.1 \%\right)$ (Table 2). The abundant clay minerals in Soil A may have provided sorption surfaces for iron species and, hence, the strongly adsorbed ferrous ions may not have been susceptible to oxidation.

\section{Conclusions}

This study of the two barren soils has shown that they are quite different in chemistry and mineralogy, and in their iron derivation, occupation sites and valences. The soil derived 
from sodic granites has a greater abundance of iron and rare earth elements than that derived from aluminous granite. The Fe occurs in different minerals including hematite and goethite plus minor aegirines in the former soil; vermiculite-chlorite and less hematite characterize the latter soil. The distinctive ratios of ferric to total iron in the two soils are attributed to differences in soil sources and processes.

Acknowledgments. The authors acknowledge the team of the Toskhi Uranium Study and Evaluation Project of the Nuclear Materials Authority, Cairo, Egypt for field assistance. We thank A. Ahmed of the Central Laboratories Sector, the Egyptian Mineral Resources Authority, Cairo, Egypt for X-ray diffraction analyses. Special thanks are due to D. Helman of the Department of Geological Sciences, California State University, Long Beach, for valuable comments on the manuscript. We gratefully thank the Editor (Marek Michalik), Michal Skiba, and one anonymous reviewer for suggestions that significantly improved the article.

\section{References}

Amarasiriwardena, D. D., DeGrave, E., Bowen, L. H., Weed, S.B. (1986). Quantitative determination of aluminum-substituted goethite-hematite mixtures by Mössbauer Spectroscopy. Clays and Clay Minerals, 34(3), 250-256.

Badreddine, R., Grandjean, F., Vandormael, D., Fransolet, A.M., \& Long, G.J. (2000). An ${ }^{57}$ Fe Mössbauer spectral study of vermiculitization in the Palabora Complex, Republic of South Africa. Clay Minerals, 35(4), 653-663. DOI: $10.1180 / 000985500547115$.

Badreddine, R., Vandormael, D., Fransolet, A.M., Long, G.J., Stone, W.E.E., \& Grandjean, F. (2002). A comparative X-ray diffraction, Mössbauer and NMR spectroscopic study of the vermiculites from Béni Bousera, Morocco and Palabora, Republic of South Africa. Clay Minerals, 37, 367-376. DOI: 10.1180/0009855023720040.

Cornell, R.M., \& Schwertmann, U. (2003). The iron oxides: structure, properties, reactions, occurrences and uses. Wiley-VCH. DOI: 10.1002/3527602097.

Egyptian Geological Survey and Mining Authority (1981). Geological map of Egypt, scale 1:2,000,000. Abbasyia, Cairo, Egypt: Geological Survey and Mining Authority.

Gunnlaugsson, H.P. (2006). A simple model to extract hyperfine interaction distributions from Mössbauer spectra, Hyperfine Interactions, 167, 851-854. DOI: 10.1007/s10751-006-9380-8

Hassan, K.M (2005). Geochemical assessment of radioactive lava pockets in El-Seboah granite, Toshki area, south Western Desert. Annales of the Geological Survey of Egypt and Mining Authority, 28, 195-204.

Hassan, K.M. (2008). Petrography, chemistry and radioactivity of granitoids at north Gebel Seri, south Western Desert, Egypt. Isotope and Radiation Research, 40(3), 615-629.

Hassan, K.M. (2009). Characterization of granites by ${ }^{57}$ Fe Mössbauer spectroscopy. Mineralogia, 40(1-4), 95-106. DOI: 10.2478/v10002-009-0008-x.

Hassan, K.M. (2010). Valences and site characteristics of iron in radioactive magmatic veins (Egypt): A Mössbauer and chemical study. Mineralogia, 41(1-2), 23-33. DOI: 10.2478/v10002-010-0003-2.

Harward, M.E, Carstea, D.D., \& Sayegh, A.H. (1969). Properties of vermiculites and smectites: Expansion and collapse. Clays and Clay Minerals, 16, 437-447.

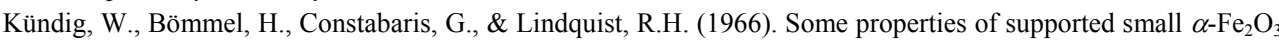
particles determined with the Mössbauer effect, Physical Review, 142(2), 327-333.

List, F.K., El-Gaby, S., \& Tehrni, R. (1989). The basement rocks in the Eastern and Western Deserts and Sinai. In M. Hermina, E., Klitzsch \& S. List (Eds.). Stratigraphic lexicon and explanatory note to the geologic map of Egypt 1:500000 (pp. 33-56). Cairo, Egypt: Egyptian General Petroleum Corporation.

Mørup, S., Madson, B.M., Frank, J., Villadsen, J., \& Kock, C.J.W. (1983). A new interpretation of Mössbauer spectra of microcrystalline goethites: "supper-ferromagnetism" or "supper-spin-glass" behavior. Journal of Magnetism and Magnetic Materials, 40, 163-174. 
Nørnberg, P., Schwertmann, U., Stanjek, H., Andersen, T., \& Gunnlaugsson, H. P., (2004). Mineralogy of a burned soil compared with four anomalously red Quaternary deposits in Denmark. Clay Minerals, 39(1), 8598. DOI: $10.1180 / 0009855043910122$

Sabet, A.H. (1972). On the stratigraphy of basement rocks of Egypt. Annals of the Geological Survey of Egypt, 2, 79-102.

Talyor, G.L., Routsala, A.P., \& Keeling, Jr., R.O. (1968). Analysis of iron in layer silicates by Mössbauer spectroscopy. Clay Minerals, 16(5), 381-391.

Vandenberghe, R.E., De Grave, E., De Geyter, G. \& Landuydde, C. (1986). Characterization of goethite and hematite in a Tunisian soil profile by Mössbauer spectroscopy. Clays and Clay Minerals, 34(3), 275-280.

Vandenberghe, R.E., De Grave, E., Hus, J.J., \& Han, J. (1992). Characterization of Chinese loess and associated paleosol by Mössbauer spectroscopy, Hyperfine Interactions, 70, 977-980.

Vandenberghe, R.E., Hus, J.J., \& De Grave, E. (1998). Evidence from Mössbauer spectroscopy of neo-formation of magnetite/maghemite in the soils of loess/paleosol sequences in China, Hyperfine Interactions, 117, 359369.

Vendelboe, A.L., Gunnlaugsson, H. P., Helgason, Ö., \& Nørnberg, P. (2005). Characterization of burned soil profiles by Mössbauer spectroscopy. Hyperfine Interactions, 166, 517-522. DOI: 10.1007/s10751-006-9319- 


\section{Erratum of the paper titled:}

Preservation of magmatic signals in metavolcanics from Wedel Jarlsberg Land, SW Svalbard

by Goluchowska et al., published in Mineralogia, 43 (2012), No 3-4: 179-197

Page 180:

"This exotic block is thrust on top of conglomerates and limestones of Ordovician age (Armstrong et al. 1986) and Silurian turbidites (Scrutton et al. 1976). Dallmeyer et al. (1990) determined an ${ }^{40} \mathrm{Ar} /{ }^{39} \mathrm{Ar}$ cooling age of 470 Ma for the Vestgötabreen Complex. In the southern part, Mesozoic and Neoproterozoic metamorphic basement of the Isbjørnhamna, Eimfjellet and Deilegga groups occur (Birkenmajer 1991)."

should be replaced with:

"This exotic block is thrust on top of Ediacaran conglomerates and is covered by conglomerates and limestones of Ordovician age (Armstrong et al. 1986) and Silurian turbidites (Scrutton et al. 1976). Dallmeyer et al. (1990) determined an ${ }^{40} \mathrm{Ar} /{ }^{39} \mathrm{Ar}$ cooling age of $470 \mathrm{Ma}$ for the Vestgötabreen Complex. In the southern part, Mesoproterozoic and Neoproterozoic metamorphic basement of the Isbjørnhamna, Eimfjellet and Deilegga groups occur (Birkenmajer 1991)." 